\title{
Proceeding
}

9th INSHS International Christmas Sport Scientific Conference, 4-6 December 2014. International Network of Sport and Health

Science. Szombathely, Hungary

\section{Hermeneutics of (sport) heroism}

\author{
ONDŘEJ ŠTAUD , JOSEF OBORNÝ \\ Faculty of Physical Education and Sport, Comenius University, Bratislava, Slovakia
}

\begin{abstract}
Štaud, O., \& Oborný, J. (2015). Hermeneutics of (sport) heroism J. Hum. Sport Exerc., 9(Proc1), pp.S320S329. The work is based on an interpretation of heroism and its specific forms in comparison with the possible heroism of sports. The first part discusses the definition of heroism and then we acquaint with selected concepts of heroism (Campbell's conception, interpretation of literary myths, Christian heroism, Carlyle's interpretation of heroism and Boorstin's "Graphical Revolution"). The second part follows in critical perspectives of the possibility of sports heroism (Zdebska, Jirásek, Robertson, Sheler, and Hyland). In the results appear the syntheses of these two parts, which appraise the possibilities of the athletes as heroes. We notice mainly the fact that the potential sports hero is missing many aspects of classical heroes. In addition of that, most of mentioned Critics claim that sporting events is out of real world and it is a sort of theater with no real ties to the world. Key words: HEROES, SPORT HEROES, INTERPRETATIONS
\end{abstract}

\footnotetext{
Corresponding author. Vajanského nábrežie, Staré Mesto, 81102 Bratislava, Eslovaquia E-mail: Ondrej.staud@fsport.iniba.sk 9th INSHS International Christmas Sport Scientific Conference, 4-6 December 2014. International Network of Sport and Health Science. Szombathely, Hungary.

JOURNAL OF HUMAN SPORT \& EXERCISE ISSN 1988-5202

(c) Faculty of Education. University of Alicante doi:10.14198/jhse.2015.10.Proc1.21
} 


\section{INTRODUCTION}

Nowadays, we are witnesses to large terminology arbitrariness, that is, when some expressions are often presented unsuitably and without feeling including our terms hero and heroism. Therefore, this paper aims to compare the approaches and conceptions of classical heroism and a critical point of view of sports heroism. We want to elaborate on the discussion on the theme of hermeneutics of classical heroism and especially on the differences between interpretation and options of sports heroism. Thus, we partially follow issues which were ruminated by sport sociologists, who developed a theory based on the transformation of sport heroism at the turn of $20^{\text {th }}$ and $21^{\text {th }}$ century (e.g. Smart, 2005 or Sekot, 2008). Firstly, we will point out a more extensive part on a more detailed general definition of heroism and then focus on selected crucial conceptions of heroism. We will start with an explanation of myths from Joseph Campbell; subsequently we shall continue by analyzing heroes within folk literature, Christian and Middle Age heroism, a description of worshipping by Thomas Carlyle and then conclude the first section with a critical theory of the "Graphical Revolution" from Daniel Boorstin as well as from critics of mass culture. In the second part, we will look at the possible theories of sports heroism, where we will gradually be introduced to the opinions of Zdebska, Jirásek, Robertson, Sheler and Hyland. In conclusion, we will offer a synthesis on both of these attitudes and primarily evaluate the possibility of sports heroism in connection with the mentioned approaches.

\section{Methodology}

From a methodological point of view in this work, two methods will be used. The first method used is the application of historical and etymologic specification of heroism by way of explication of discriminant and selective analysis. We approach the problem of sports heroism analogically and by using a method of critical analysis. The second method is the synthesis of these specifications and a comparison between classical and sports heroism shall follow

\section{RESULTS}

\section{Etymology of the word hero and the concept of heroism}

To begin, we proceed with the definition from the Large Dictionary of Sociology (Velký sociologický slovník), where a hero is a person who performs significant deeds of bravery, usually with risk to his own life, and therefore he (she) is presented as a role model of behavior ${ }^{2}$. Heros are commonly ascribed the following attributes: bravery, fearlessness, ability to perform risk, selflessness, persistence and sometimes also intelligence although this isn't a significant attribute (Velký sociologický slovník, 1996) ${ }^{3}$

In ancient Greece the term "Heros" means soul of deceased person which could possibly intervene into the life of others. Later, it was in this way that they named people who performed significant deeds and so old Greeks thought that these people who performed such mentioned significant deeds was because of their divine blood. We can name demigods such as Achilles or Heracles as examples (Souriau, 1994). Usually a

In the "old" Dictionary of Ethics, heroism is also defined as "unusual form of human behavior which is, from a moral point of view, a heroic deed". A hero decides to solve extraordinary tasks and he is more responsible as he has more obligations than is usual among average people and, at the same time, he overcomes exceptional obstacles (Kon, 1978, p. 79).

Dictionary of anthropology delimits hero in a historic and cultural perspective in the following definition: in many mythologies or old historiography from various parts of the world the hero is an animal, human, demigod or god which brings to people various cultural achievements (e.g. fire, agricultural crops, writing); nevertheless sometimes he is punished because of that.
S321
| 2015 | Proc1 | VOLUME 10
C 2015 University of Alicante 
myth was made up around these people. In later years, great important people such as philosophers, scholars or rulers were regarded as heroes (the founder of antic Sparta Lycurgus or Aeschylus, Sophocles, Plato etc.). In later times we can speak about the specific cult, which arose around them and then significantly expanded.

Myths of secular heroes began to be created in the 9th and 10th century together with ideals of chivalry which was an inspiration of the new image of the romantic hero. He willingly lays down his life for ideals, love, homeland etc. (Le Goff, 2002). Nevertheless, the image of idealized legends of knights is necessary to relate and emphasize because of their ethical values (Seman, 2014). Eco says that the most general form of a hero's myth is in the form of a novel. A novel's hero is similar to an average person even though he is outstanding in some areas of life (Eco, 2006).

In addition to history and sociology, the sociology of morals is an important part of the category of heroes, because a hero symbolizes an important moral feeling and maximal identification with certain moral standards. From a psychological point of view, a hero is interesting because he suppresses selfpreservation and accentuates the role of superego. From a psychological perspective, this is an important piece from Carl Gustav Jung - Hero and archetype of mother (Jung, 2009). The concept of heroism is seen as a label related to great prestige and alternatively, to a positive sign of abnormality. Nevertheless, heroism has various interpretations which unfold by referred groups, society and time. Heroes particularly occur in significant historic moments (wars, revolution etc.) which also raises the meaning of this term. These times are used as motivators as well as for propaganda (Velký sociologický slovník, 1996).

According to Klapp (1962), heroes and heroic narratives serve a variety of social functions: as role models embodying public values and ideals and as unifying social forces which transport an audience vicariously out of everyday roles into a new kind of reality that has laws and patterns different from ordinary social structure. Klapp also stated: as compensatory symbols who console people for their recognized lack of what a hero represents and what people think they ought to be but aren't (1962, pp. 139). Strate (1994) argues for the rule that members of society are separated from their heroes by time, space and by social class as well. Therefore, people know their heroes only through stories, pictures and other forms of information. So in that case, we don't have heroes in the literal sense of the word but only a communicated image of them (Strate, 1994, cited by Vande Berg, 1998).

We can see heroes even in a pejorative way, especially in the fifties of the twentieth century in countries of The Eastern Bloc. Here, a hero was usually a working labourer, not only a symbol of socialist-realist arts but as a symbol of the communist world. He was mighty, healthy, strong and full of optimism and proud of his work (Pavis, 2003).

If we could synthesize the above, then we can accentuate that every society and every ideology has aspired to the mass acceptance of needing heroes as role models of behavior, particularly those societies and ideologies with state-built ambitions. Ideal types of heroes are based on real people and deeds but they are completed through a myth-created process. A lack of heroes in the level of role models and imitation is regarded as a mark of decline in social integrity and viability of society. Therefore, there still exists a cult of national and war heroes (Velký sociologický slovník, 1996).

Firstly, it is necessary to mention the American mythologist Joseph Campbell and his piece "The Hero with a Thousand Faces". Campbell searched deeply for the substance of myths in religion doctrine and in various mythologies. Thus, we speak about the model of the mythological hero who has appeared in similar 
variations on different continents, however his destiny is in most cases almost identical. A hero is also a person, who despite his personal or other restraints, is capable of faith for general validity standards. According to Campbell, a hero creates a pattern which is presented by transitional rituals. These rituals are separation, initiation and return. He calls this pattern a basic unit of the so-called "Monomyth" or one hero's adventure (Campbell, 2000, pp. 41). The hero of a certain monomyth is a person with outstanding natural abilities. In his society he is usually worshiped but he can also be overlooked. He and his world suffer from symbolized deficiencies. This lack can be the loss of a gold ring or by contrast it can be the apocalypse with the destruction of the world. Thus, we can meet the hero in fairy tales where he doesn't cross the threshold of his "little world" or the hero whose faith is within a macrocosm (e.g. Buddha, Jesus Chris or Mohamed who bring messages to the whole world).

Each phase of the monomyth has relatively invariable rules. The first phase is that of the hero's mythological journey and is his fatal move away from the spiritual center of his society. This new area can be expressed as a foreign country, forest, deep sleep etc. On the border between the first and the second phase he has to overcome a magic threshold. It appears almost as if the hero has died (Campbell, 2000) Beyond this threshold the hero goes through a process of tests and the ease in which he performs the adventurous deeds suggest to us that he is a great man. The second phase is the initiation or apotheoses when he is accepted among the gods. The third phase is his return because the rules of the monomyth require a closed circle. Now the hero must bring back to the real world his holy treasures which consequently contribute to the renewal of fellowship, nation or the whole world. Nevertheless, a crucial problem is in the hero's transcendental experiences. He isn't sure whether society will understand and accept his message (Cambpell, 2000). This is the main key to understanding myths and symbols. We can use the example of Jesus Christ. In the Gospel of saint Matthew (Matthew, 10:35) it is said: "He who loses one's own life for me, he will find it". Here it is possible to see the metaphor of Christ's suffering and the subsequent resurrection and dissemination of this story among his disciples and also among other people. Thus, the hero was representative of two perspectives, remaining also after death as a synthesized image; the hero is only sleeping and he will rise up again at the last hour or he is living among us in another form (Campbell, 2000).

\section{'Campbell's hero approach'}

Firstly, it is necessary to mention the American mythologist Joseph Campbell and his piece "The Hero with a Thousand Faces". Campbell searched deeply for the substance of myths in religion doctrine and in various mythologies. Thus, we speak about the model of the mythological hero who has appeared in similar variations on different continents, however his destiny is in most cases almost identical. A hero is also a person, who despite his personal or other restraints, is capable of faith for general validity standards. According to Campbell, a hero creates a pattern which is presented by transitional rituals. These rituals are separation, initiation and return. He calls this pattern a basic unit of the so-called "Monomyth" or one hero's adventure (Campbell, 2000, pp. 41). The hero of a certain monomyth is a person with outstanding natural abilities. In his society he is usually worshiped but he can also be overlooked. He and his world suffer from symbolized deficiencies. This lack can be the loss of a gold ring or by contrast it can be the apocalypse with the destruction of the world. Thus, we can meet the hero in fairy tales where he doesn't cross the threshold of his "little world" or the hero whose faith is within a macrocosm (e.g. Buddha, Jesus Chris or Mohamed who bring messages to the whole world).

Each phase of the monomyth has relatively invariable rules. The first phase is that of the hero's mythological journey and is his fatal move away from the spiritual center of his society. This new area can be expressed as a foreign country, forest, deep sleep etc. On the border between the first and the second 
phase he has to overcome a magic threshold. It appears almost as if the hero has died (Campbell, 2000) Beyond this threshold the hero goes through a process of tests and the ease in which he performs the adventurous deeds suggest to us that he is a great man. The second phase is the initiation or apotheoses when he is accepted among the gods. The third phase is his return because the rules of the monomyth require a closed circle. Now the hero must bring back to the real world his holy treasures which consequently contribute to the renewal of fellowship, nation or the whole world. Nevertheless, a crucial problem is in the hero's transcendental experiences. He isn't sure whether society will understand and accept his message (Cambpell, 2000). This is the main key to understanding myths and symbols. We can use the example of Jesus Christ. In the Gospel of saint Matthew (Matthew, 10:35) it is said: "He who loses one's own life for me, he will find it". Here it is possible to see the metaphor of Christ's suffering and the subsequent resurrection and dissemination of this story among his disciples and also among other people. Thus, the hero was representative of two perspectives, remaining also after death as a synthesized image; the hero is only sleeping and he will rise up again at the last hour or he is living among us in another form (Campbell, 2000).

\section{'Boorstin's interpretation of Ancient Greek heroism'}

As a follow-up to Campbell's universal concept of hero myths, we will briefly examine the interpretation of Ancient Greek heroism according to the historian Daniel Boorstin. These myths are considered to be witnesses of heroism, e.g. Homer's Odyssey, the legend about Heracles and many others. These mentioned epics describe the deeds of people who resist God's wrath. Nevertheless, we don't speak only about a narrative but also about a holy text of morals and religion. According to Ancient Greeks, the heroic figures gave their history a real and writeable form with clear sense. Here, tradition wasn't preserved just by chaotic folk literature but these figures were also immortalized in heroic poetic pieces. Throughout all these myths, everybody becomes acquainted with monumental ages about superhuman creatures and miraculous events which exceed our daily experiences.

\section{'Ong's "heavy figures"'}

For a better understanding of Boorstin's interpretation of Greek figures we can emphasize that in communicative cultures, heroes were known through poems and songs that were often performed in public spaces. As a result of the transience of the spoken word, and the fact that relatively little information can be stored in oral poetry and song, early heroic narratives tended to focus on memorable, larger-than-life deeds of a limited number of individuals. As cultural historical Walter Ong (1981) explains, oral heroes were "heavy figures". Thus the epic hero, from one point of view, appears as an answer to the problem of knowledge storage and communication in oral-aural cultures where indeed storage and communication are virtually the same thing (pp. 205).

With the advent of the print medium, however, the nature of heroes changed. The limitations of human memory were overcome with print because information can be stored. E.g. Strate (1994) explains that heroes became more individualized and more realistic as a result: With the presence of a means to store information outside of collective memory. "The heavy figures" of myth and legend were no longer necessary, and greater numbers of lighter heroes were made possible. As oral poetry and song were replaced by written history, the hero was brought down to earth, and as more information could be stored about any given individual, heroes became individualized. The heroes of literature cultures are realistic, mortal figures, objects not of worship, but of admiration (Strate, 1994, cited by Vande Berg, 1998).

\section{'Christian heroism'}


Christian religion is a relatively crucial concept of heroes and heroic deeds. It indirectly follows Campbell's concept of myths. Firstly, we have to realize that Christian legends and heroes unlike Campbell and Greek myths are still alive and worshiped even today. Although it can be seen as an anachronism, the adoration or beautification of saints are apparent in many countries and are permanent. The basic points in Christian heroism are saints and canonization. In earlier times, saints were canonized spontaneously, usually we speak about them as martyrs (who willingly died for teaching of Jesus Christ or for Christian virtues or devout deed) or devotees (they didn't have to die)(Attwater, 1993). In later times, canonization depended on precise regulation and this state is still valid. If it is known that someone excelled in extraordinary virtue and allegedly performed miracles, then a rigorous inquiry took place where he (she) lived as well as in Rome. A saint is man or woman who devotes to God heroically. We can find saints among people with various statuses from priests, from kings or artists, to beggars. Pope Benedict XIV said: "A saint is a Christian who for heroic virtue and for miracles from God and due to God's intercession, was included by the Church in the list of saints". Exceptionality can depend on the greatness of peace made for God and the salvation of souls in heavy fighting. Also important are the efforts, self-denial and sacrifices for God and all of these deeds must be made joyfully and persistently" (cited by Vondruška, 1930, pp. 9).

'Carlyle's heroes'

Very important and inspirational is also the work of Thomas Carlyle "On Heroes and Hero Worship and the Heroic in History". His description is based particularly on considerations how heroes were adopted, changes in this adoption and what people regarded as esteem for heroes and heroism in human history (Carlyle, 1925). Primarily important as well is the orientation on specific form of heroes which are divided by chronological order from Old Germanic myths to Napoleon.

Firstly, Carlyle sees the hero as a God, and represents him as Germanic Odin from Scandinavian myth. Worshipping a God-like hero in religion is the most important thing for humans and also for all society. Worshipping here means the manifestation of unlimited esteem. He likewise thinks that esteem for heroes was a great factor in the system of ideas at that time (Carlyle 1925, pp. 20).

The next form of hero is something like the Islamic prophet Mohamed. He is not a God but a human who is by enlightened by God. After that there are heroes such as poets and writers where Dante Alighieri and William Shakespeare are mentioned. Gods and prophets are creations of times long past and they don't occur today. Carlyle says: "A poet is a heroic man who belongs to all ages. He is introduced to the world and he becomes the property of all ages" (Carlyle 1925, pp. 89). Similarly, these are found in the writings of Samuel Johnson, Jean-Jacques Rousseau and Robert Burns. Among poets and writers, Carlyle mentions also priests; namely the reformer Martin Luther and the puritan John Knox who in the time of the reformation were regarded as heroes by many people. The last of Carlyle's heroes are kings and exemplary personalities such as Oliver Cromwell and Napoleon Bonaparte. Kings embody the commander of the people and our will has to submit to him. The king can be considered as the most excellent of all great people (Carlyle, 1925).

'Deformation of heroism or Boorstin's "Graphical Revolution"'

If we have described in the previous theories heroic greatness and nobility mainly as a form from very old times, we will now move up to the 20th century when classic heroism started to deform under the weight of quick and easy reproducibility. In this context, we will talk about the concept of the "Graphical Revolution" from the previously mentioned historian Daniel Boorstin. This expresses the overproduction of visual material and the possibilities of visual perception. This excess of production had and has a negative influence on the unwitting perception of people. From our point of view, Boorstin's work and his approach to 
American (or global) history is important particularly with respect to understanding the term heroism and its slow replacement by other forms of human perfection. Overall, it is a way of thinking about the greatness of people from which the Graphical revolution was changed.

According to Boorstin's concept, the traditional heroic type included figures as diverse as Moses, Ulysses, Aeneas, Jesus, Caesar, Mohammed, Joan of Arc, Shakespeare, Washington, Napoleon and Lincoln. For our purposes it is sufficient to define a hero as a human figure - real or imaginary or both - who has shown greatness in some achievement. He is a man or woman of great deeds (Boorstin 1963, p. 59).

In the last one hundred and fifty years the old heroic human form has been broken and a new form has been made. We have actually demanded that this form be made, so that marketable human models modern "heroes" - could be mass-produced to satisfy the market without any hitches. The qualities which now commonly make a man or woman into a "nationally advertised" brand are in fact a new category of human emptiness. But celebrity-worship and hero-worship should not be confused. Unfortunately we confuse them every day, and by doing so we come dangerously close to depriving ourselves of all real models.

Nevertheless, we must mention just one important factor, the hero was distinguished by his achievement; the celebrity by his image or trademark. The hero created himself; the celebrity is created by the media. The hero was a big man; the celebrity is a big name. The hero was born of time: his gestation required at least a generation. As the saying went, he had "stood the test of time". A maker of tradition, he was himself made by tradition. The celebrity, on the contrary, is always a contemporary (Boorstin, 1963).

Similar ideas in the cultural sphere like Boorstin are representative of the Frankfurt school of critical theory by Theodor Adorno and Max Horkheimer who create again a concept about cultural industry (Adorno \& Horkheimer, 2009). Adorno alone speaks about "Fetish character in music and regression of hearing", where the main goal is to impose deformed arts and opinions on people (Jirák \& Köpplová, 2003).

\section{Synthesis of hero's concepts with concepts of sport heroism}

Now we will immerse ourselves into the concept of sports heroism. This problem has been examined by several sports sociologists and philosophers. Sociologist Halina Zdebska directly confronts mythic heroism and the forms of sports heroism. In her analysis we can find out that potential sports heroes must participate on the highest level of a given sport. His athletic discipline must be popular in the given area, and the athlete must simultaneously have a positive attitude towards the rules and moral norms as well as be perfect in other spheres of life. Nevertheless, in contrary with other mentioned approaches to heroism (e.g. Campbell or Ancient Greek myths) sport doesn't require heroic deeds in real moments. We can consequently observe certain similarities in the world of film, theatre or opera. Sport is actually an event closed inside an area resembling the theater although with one considerable feature; it is drama with an open scenario. It is a play without a known end, even though we can probably guess it (Zdebska, 2006).

A sports hero also stands between the spiritual and secular spheres of social life. At this time sport doesn't contain any religious values (here is the main difference from Christian attitudes). We can see it rather as a memory or cross-section of entertainment which is placed between these two spheres. Even though sport can give us a certain sacral dimension (if it contains any ceremonial values, solemn rituals etc.). Thus sports heroes can be in certain conditions considered cultural heroes as well (Zdebska, 2006). 
Interesting as well is the theory of Max Scheler (2003) where a hero is "an heir of blood" which designates him to a higher extent than for e.g. genius. A heroic deed is also anything else other than ordinary human activity, and a hero is of human will. Scheler says (which is mentioned below) that typical features of a hero are greatness of will, power, bravery, generosity, the joy of struggle and so on. In this way Scheler's hero is similar to a sports hero. Nevertheless, a sports hero is somewhat poorer; he is missing one important layer. An athlete can be understood as "an heir of blood", but this heir can be understood in the sense of his representation of only a certain culture of society. Real heroes are connected to the real world and faith for the true world. This is the reason that sports heroes cannot be equal to e.g. heroes of war (Zdebska, 2006). Other theorists who deal with this problem are Jirásek and Robertson (2010). In connection with sports heroism, they emphasize the problem of victory at any cost when such an adoration of victory which overshadows personal values (health or honour) cannot be the feature of a hero. They also say that sports heroes are called those persons who assimilate with the contemporary world and its form is of a onedimensional hero whose main goal is victory. Together, they also point out the transformation of Homer's hero archetype interconnected by body strength with intellect and sympathy ("a big heart") to the hero of one dimension - corporality (Jirásek \& Robertson, 2010).

Jirásek as well stresses that a hero (also as an athlete) naturally attracts attention by his brave deeds which are perceived as a higher purpose. The condition of heroism isn't only his attitude and deeds but also the fact if the hero transcends or not. Likewise, a sports hero can achieve proof of perfection by human effort in the fight for victory through physical, psychological, spiritual and social means. But a hero isn't here because he decided to be; heroism isn't a question of will or rational maneuver (Jirásek, 2005).

Drew Hyland (1990) also sees the problem similarly to Zdebska. According to him, people adore athletes because of their extraordinary dexterity and agility. In ancient cultures, people worshiped heroes because of their ability to fight, physical strength and bravery which we can see in athletes today. The hero status of athletes is thus a nostalgia for the past. Nevertheless, similarly to Zdebska, Hyland emphasizes that unlike earlier times, sport and sporting events which don't have a connection to the real world. Hyland bluntly says that watching is an unproductive activity and it is basically a waste of time. Further still is the opinion of Edward Shils who not only equates athletes to heroes, but equates them with low-quality entertainers and arguable creators of so-called brutal culture (Shils, 1961). For the sake of objectivity we can mention Kosiewicz's (2006) opinion on sport and theatre. Football or basketball players perform with balls and similar "things" like a circus artist in a circus ring. He points out also some noble analogies of sports movement, e.g. in the field of art. The basic ingredient of sport and theatrical events is movement. The main participants, with its help, perform scenic acts as is the situation in a stadium. Dynamic and complicated forms of movement similar to show characters are done in sports as well e.g. volleyball, rugby, martial arts or gymnastics (Kosiewicz, 2006, p. 356). Thus, heroic deeds in sport is not at the beginning of the sporting activity (intended to perform a heroic sporting deed), but in its conclusion, a particularly objective and real form of extraordinary human deed.

\section{DISCUSSION AND CONCLUSION}

If we look at all of the above mentioned theories we can say that synthesizing elements correlates with potential forms of sports heroes. In Campbell's concept a hero's world always has some shortage; a hero also undergoes an initiation which is incomprehensible for ordinary mortal people. The hero's return is also somewhat more difficult. Just in these items is the difference between Campbell's hero and a sports hero. The concept of Ancient Greek myths and Ong's concept of "heavy figures" was valid in the world of sport only at the time of the Ancient Greek Olympics, but in the time of modern sport and modern communication 
it has no relevancy. In this way a potential sports hero becomes lost under the weight of easy reproducibility of his deeds and new communication technologies. Christian heroism cannot be synthesized with sports heroism because sport was earlier connected to pagan customs and today is practically secularized. If we look at Carlyle's work, heroes are worshiped in the same way to God, prophets, poets, writers, priests and commanders who brought a legacy to future generations and people who understood the necessity of their worship. Thus, an athlete cannot be worshipped as a hero but only admired. It is possible to say that athletes as potential heroes are closer to Boorstin's approach when they can emit features of greatness and fame. Nevertheless, it isn't clear if with the inflation of today's sports stars and celebrities can "stand the test of time" which Boorstin stresses. We must mention as well Sheler's theory where it is emphasized primarily the great will of the hero including his other qualities which a potential sports hero would have. But if we recall the objections of Zdebska, Hyland or Kosiewicz, sport is only a closed theatre without any influence on the real world. An important question is also whether victory comes at a cost of the one-dimensionality of sports triumph.

Thus, heroes must be created by themselves and their heroic ability must be proven in times of scarcity, in times of wars or in other important times. Hermeneutic is a specific explanation of heroism which reveals to us a problematic look at sports heroism and its possible interpretation.

\section{REFERENCES}

1. Adorno, T., \& Horkheimer, M. (2009). Dialektika osvícenství: filosofické fragmenty. (Vyd. 1., 247 s.) Praha: Oikoymenh

2. Attwater, D. (1993). Slovník svatých. (2., rev. a dopl. vyd., 436 s.) Vimperk: Papyrus

3. Boorstin, D. (1963). The image, or, What happend to the American dream. (1st ed., 1, 314 s.) Harmondsworth, Middleses: Penguin Books

4. Boorstin, D. (1999). Člověk hledající: přiběh lidské touhy pochopit svět a sebe sama. (317 s.) Praha: Prostor.

5. Campbell, J. (2000). Tisíc tváři hrdiny: archetyp hrdiny v proměnách věků. (Vyd. 1., 339 s.) Praha: Portál.

6. Carlyle, T. (1925). Hrdinové: úcta k hrdinům a hrdinství v dějinách. (251s.) Praha: Symposion

7. Eco, U. (2006). Skeptikové a těšitelé. (Vyd. 1., 367 s.) Praha: Argo.

8. Hyland, D. (1990). Philosophy of sport. (1st ed., xxvii, 161 p.) St. Paul: Paragon House.

9. Jirák, J., \& Köpplová, B. (2003). Média a společnost. (Vyd. 1., 207 s.) Praha: Portál.

10. Jirásek, I., Robertson, D. (2010) The Hero in Victory and Loss. In Acta Univ. Palacki, Gymn. 40(1).

11. Jirásek, I. (2005). Filosofická kinantropologie: setkání filosofie, těla a pohybu. (1. vyd., 354 s.) Olomouc: Univerzita Palackého v Olomouci.

12. Jung, C. (2009). Hrdina a archetyp matky: (symboly proměny II). (Vyd. 1., 478 s.) Brno: Nakladatelství Tomáše Janečka.

13. Klapp, O. (1962). Heroes, Villians, and Fools: The Changing American Character. (1st ed., s. 176) New Jersey: Prentice-Hall.

14. Kon, I. S. (1978). Etický slovník. Bratislava: Pravda

15. Kosiewicz, J. (2006). Filozoficzne aspekty kultury fizycznej i sportu. Wydanie III. Warszawa: Wydawnictvo BK. ISBN 83-916859-7-7.

16. Le Goff, J., Schmitt, J., \& Alessio, F. (2002). Encyklopedie středověku. (1. vyd., 935 s.) Praha: Vyšehrad. 
17. Malina, J. a kol. (2009). Antropologický slovník (s priihlédnutím k dějinám literatury a umění) aneb co by mohl o člověku vědět každý člověk Brno: Akademické nakladatelství CERM v Brně, 2009. ISBN 978-80-7204-560-0.

18. Ong, J. W. (1981) Fighting for life: contest, sexuality, consciusness. Ithaca : Cornell University Press.

19. Pavis, P., \& Jobertová, D. (2003). Divadelní slovník: [slovník divadelních pojmů]. (Vyd. 1., 493 s.) Praha: Divadelní ústav.

20. Scheler, M. (2003). Můj filosofický pohled na svět. (Vyd. 1., 284 s.) Praha: Vyšehrad.

21. Sekot, A. (2008). Sociologické problémy sportu. (Vyd. 1., 223 s.) Praha: Grada.

22. Seman, F. (2014) Rytier - „vzor mužskej dokonalosti“. In Tělesná Výchova A Šport, 245,(4). pp.1822.

23. Shils, E. (1961). Mass society and its culture. In Jacobs, N. Culture for the Millions. Princeton, NJ.: D. Van Nostrand

24. Smart, B. (2005). The sport star. (1st ed., 217 s.) London: SAGE Publications.

25. Souriau, É. (1994). Encyklopedie estetiky. (939 s.) Praha: Victoria Publishing.

26. Vande Berg, L. (1998). The Sports Hero Meets Mediated Celebrityhood. In Wenner, L. Mediasport. (xiv, 336 p.) London: Routledge.

27. Velký sociologický slovník. (1996). (Vyd. 1, 747 s.) Praha: Karolinum.

28. Vondruška, I. (1930). Životopisy svatých v pořadí dějin církevních. (Vyd. 1, 342 s.) Praha: Ladislav Kuncír.

29. Zdebska, H. (2006). The sports hero phenomenon. In Journal Of Lithuanian Sports Science Council, Lithuanian Olympic Academy, Lithuanian Academy Of Physical Education And Vilnius Pedagogical University, 45(3), pp. 15-21. 